\title{
JUURNAL.RU
}

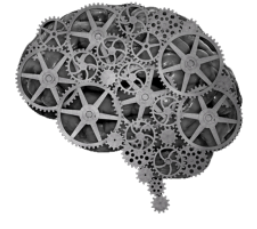

COMPANY GROUP "INTELLEKT"

\author{
Кумпан Н.А., Агапова Е.А. \\ ИФиСПН ЮФУ \\ Ростов-на-Дону, Россия
}

doi: 10.18411/1j2016-5-3-08

\section{К проблеме эмиграции и адаптации русских граждан в США}

Аннотация. В статье описывается эмиграция русских граждан в Америку. Как и любое явление, данный процесс должен быть обусловлен рядом причин, основными из которых стали политическое, экономическое и социальное состояние родного государства. Но переехав в другую страну, каждый сталкивается с определенными трудностями; возникают проблемы адаптации. Таким образом, в нашей работе мы рассмотрим основные аспекты адаптационного процесса.

Ключевые слова: иммиграция, адаптация, дезадаптационный синдром.

Сейчас проблема иммиграции стоит наиболее остро. Этому свидетельствует огромный поток жителей из Африки в Европу, из России в США. Люди всегда стараются перейти на ту землю, где будут наиболее благоприятные условия для проживания. В связи с тем, что каждый год РФ покидают около нескольких десятков граждан, проблема иммиграции для нашего государства, является немаловажной, поэтому именно данной теме будет посвящена наша статья. Изучив литературу, посвященную русской иммиграции, мы пришли к выводу, что существует ряд проблем, касающихся адаптационного процесса. Этот вопрос очень интересен, т.к. поток иммигрантов с каждым годом растет.

В начале XX века вышла книга Г. Смолянского, посвященная проблеме массовой эмиграции из Российской империи в США. 
Однако первой и долгое время единственной работой о расселении, социально-экономическом положении русских иммигрантов стала книга М.Е. Вильчура. А уже в 1919 году в Калифорнии опубликовали небольшое исследование Л. Соколовой о молоканах в Лос-Анджелесе.

Таким образом, интерес к русской иммиграции рос с каждым днем. Несмотря на то, что Россия не была первой в списке стран, граждане которых иммигрировали в США, поток русских граждан был довольно высок.

В 1982 году открылся первый миграционный пост в США, на острове Эллис (рядом с островом Свободы). До этого момента любой мог приехать на постоянное место жительства в Соединенные штаты. Но с началом работы иммиграционной службы, требования к иностранцам были относительно невысокими. Было всего 29 вопросов, среди которых «имя, фамилия, возраст, страна рождения и т.д.». Но даже на этом этапе были те, кому был запрещен въезд в страну; коммунисты фашисты, проститутки. Затем необходимо было пройти медицинский осмотр (данная процедура проходит и сейчас). После чего иммигранты отправлялись на пароме в Нью-Йорк. В 1954 году этот иммиграционный пункт закрыли.

Проблему иммиграции очень долго не озвучивали. В особенности играл большую роль запрет на некоторые издания статей, журналов, газет. Но после отмены цензуры (1991-92) появилось множество статей, касающихся русского зарубежья. Описывались судьбы, проблемы, с которыми столкнулись русские иммигранты.

В настоящее время основная масса иммигрантов приезжает в Америку из Мексики, Китая, Великобритании и Канады.

Сегодня уже не так просто иммигрировать в США из-за ряда политических конфликтов России и Соединенных штатов, но все же, русские граждане продолжают покидать страну. Основными причинами стали: высокая заработная плата (этот пункт является достаточно хлипким, т.к. отношение к русским гражданам сейчас неоднозначное), экология (в России происходит 
бесконтрольная вырубка леса, что ведет к дисбалансу кислорода в воздухе, проблема радиоактивного загрязнения (АЭС)) и, наконец, политика (различие политических взглядов).

Причины, чтобы покинуть страну являются достаточно вескими. Но новая страна - это не только другая территория, это другая культура, другой менталитет, другое мировоззрение. Необходимо приспосабливаться к новым природным, экономическим, социальным условиям. Помимо этого, не все люди умеют быстро «акклиматизироваться». В этом случае речь идет о социальной адаптации. Основным способом адаптации является способность личности принять нормы и ценности новой социальной среды. Например, основной ценностью для американца является - родина. Патриотизм в США очень развит, он не имеет черт пропаганды. Жители этого государства, действительно, считают свою страну самой лучшей. Таким образом, мигранту необходимо будет оценивать и принимать культуру этой страны.

Выделяют два основных способа социальной адаптации: первый постараться окружить себя той же социальной средой, которая была в родной стране; второй - приспособиться к новому менталитету и культуре.

Первый вариант является достаточно трудоемким, особенно, если у вас нет знакомых и друзей на новом месте. Поэтому второй способ является наиболее благоприятным.

Для более подробного изучения проблем адаптации, нами было проведено исследование. Мы изучили ответы русских граждан, иммигрировавших в США, на сайте http://forum.rusrek.com/thread-449.html (форум русской иммиграции в США). Всего ответов было:47. Такое небольшое значение обусловлено несколькими факторами. Во-первых, в связи с последними геополитическими событиями, тема эмиграции и адаптации закрыта на большинстве форумов. Вовторых, редким стало явление, когда указывают точные факты, чаще описывают отличия от России. Несмотря на это, нам удалось изучить данные вышеуказанного сайта. К примеру, одной из основных проблем стало 
подтверждение уровня языка на территории США. Далее идет проблема социальной адаптации (зачастую трудно найти товарищей). Ссылаясь на изученный материал, можно описать в процентном соотношении так: на адаптацию потребовалось 0,5 лет 7 пользователям, год - 7, 2 года - 10, 3 года 11, более 10 лет (или еще не адаптировались) - 12.

Проанализировав данные этого форума, можно сделать следующие выводы:

1. Длительность адаптации у всех абсолютно разная (несмотря на знание языка);

2. Адаптационный период зависит от возраста (у пользователей, чей возраст не был старше 18, адаптационный период варьировался от 0,5 до 2 лет, а у пользователей в возрасте от 18 и до 47 - от 3 и более лет, вплоть до настоящего момента).

Процесс адаптации с возрастом усложняется, но это вполне объяснимо, т.к. человек уже полностью сформирован (ценностные ориентиры, мировоззрение). Дети гораздо легче адаптируются к новой среде.

А для взрослых процесс адаптации иногда может затянуться на многие годы. И даже в этом случае он будет не ограничен, у многих этот процесс затягивается, вплоть до «дезадаптационного синдрома».

«...так и из депрессии до сих пор выйти не могу. Антидепрессанты серьёзные пью, на них и живу...» (Речь идет о переезде в США, проблема адаптации/).

Дезадаптационный синдром - это утрата свойства организма приспосабливаться к изменениям внешней и внутренней среды.

К сожалению, этот синдром малоизучен, но уже достаточно распространен. На данный момент, различают две формы дезадаптации: острую и хроническую. Причины достаточно предсказуемы; длительный стресс, инфекции, хронические интоксикации. Избавиться от первой формы очень просто с помощью медикаментов, но, если речь идет о хронической форме, то 
большую сложность составляет тот факт, что распознать ее очень трудно. Вторая форма быстро перетекает из депрессии в синдром хронической усталости.

Запущенная форма дезадаптационного синдрома характеризуется заторможенностью, кратковременной утратой памяти, головокружением, бледностью, сухостью во рту.

Таким образом, русские граждане в США выделяют следующие факторы, влияющие на процесс адаптации: языковой барьер, суровость законов, феминизм (США - государство, где ярко выражена самостоятельность женщин) и негативное отношение к русским.

Но, несмотря на такое количество негативных факторов, и явных проблем адаптации, количество иммигрантов из России в США ежегодно растет. Так, в 2013 году из России в США иммигрировали 116220 человек, а уже в 2015 статистика показывает 204659 человек.

«Что-то в эмиграции потерял, что-то приобрел. Потерял лучшее в мире метро и худшую в мире цензуру, лишился обдирного хлеба, дома творчества в Коктебеле и необходимости писать слово “родина” с большой буквы. Кое-что приобрел. Например, американское гражданство, ломаный английский язык, концерты в Карнеги-Холл, привычку отдавать рубашки в китайскую прачечную и по любому поводу произносить слово “сорри”»

Так, своим опытом делится Марк Поповский, ветеран Великой Отечественной войне, в своем очерке «Мы здесь не первые».

Абсолютно каждый, иммигрировав в другую страну, сталкивается с разного рода проблемами адаптации, и у каждого на этот процесс уходит определенное количество времени. Конечно, есть причины, которые могут стать ключевым в решении переехать, но также есть причины отказаться от этой идеи, поэтому каждый сам решает для себя, что делать, и каждый сам отвечает на вопросы «для чего? с какой целью». 


\section{Литература:}

1. Проскурякова О.Л. «Адаптация мигрантов как социальный процесс». Оренбургский государственный университет. Вестник ОГУ№4/Апрель/2007

2. Леонтович О.А. Россия и США. Введение в межкультурную коммуникацию. Учебное пособие. Стр. 29-33. Волгоград. «Перемена». 2003

3. Электронный pecypc [http://forum.rusrek.com/thread-449.html] 